\title{
FDI (Foreign Direct Investments) as a Determinant for the Economic Growth of Nigeria (2009-2018)
}

\author{
Umutoni Flora1, Ze Tian², Joseph Obiora Ezezue ${ }^{3}$ \\ ${ }^{1}$ Department of Business Administration, Business School of Hohai University Jiangning Campus, Nanjing, China \\ ${ }^{2}$ Low Carbon Economy Research Institute, Hohai University Changzhou Campus, Changzhou, China \\ ${ }^{3}$ Plot 243/244 Transobibia Layout, Awka, Nigeria \\ Email: floramulan@gmail.com, tianze21@126.com, obioraezezue@gmail.com
}

How to cite this paper: Flora, U., Tian, Z. and Ezezue, J.O. (2020) FDI (Foreign Direct Investments) as a Determinant for the Economic Growth of Nigeria (2009-2018). Open Journal of Business and Management, 8, 770-782.

https://doi.org/10.4236/ojbm.2020.82047

Received: February 3, 2020

Accepted: March 17, 2020

Published: March 20, 2020

Copyright $\odot 2020$ by author(s) and Scientific Research Publishing Inc. This work is licensed under the Creative Commons Attribution International License (CC BY 4.0).

http://creativecommons.org/licenses/by/4.0/

\begin{abstract}
This research examined the impact FDI (foreign direct investments) had on the economic growth of Nigeria between 2009 and 2018. The research was directed using 3 research questions while the expo facto approach was utilized. The applied data was utilized as secondary data and it was gathered from the stock exchange of Nigeria. The collected data covered a duration of ten years and it was analyzed using the OLS (ordinary least square) technique with the help of E-view 9. The findings of the study showed that FDI has a considerable impact on the labor force, inflation, and manufacturing sectors of Nigeria. The research suggested that private sector investments with modern equipment are needed for investing in the economy of Nigeria. Additionally, the research suggested that Nigeria's policy on foreign investment should aim to attract and encourage more foreign capital inflows by proposing economic programs that include businesses' expansion and measures that are easier to set up.
\end{abstract}

\section{Keywords}

FDI, Economic Growth, Manufacturing, Labor Force, Inflation

\section{Introduction}

After the recent wave of globalization, the attitude of most developing nations has notably transformed. This growth is indicated by the necessity to make available a friendly environment to investments so as to be at par with the globalization trend. To accomplish this goal, the developing nations are more prepared to provide many non-financial and financial incentives to MNCs (Multi- 
national corporations) in an attempt to motivate them to increase the flows of direct investments through capital return. To find the highest capital return, economists favor the free capital movement across the country's borders. It's against this setting that MNCs seek to invest in foreign nations that have a reasonable risk. Nigeria is considered to be an extremely high-risk investment. However, due to some hindrances by the government of Nigeria, which includes unstable macro-economic policies and bad governance, investment is the way out from the underdevelopment state of Nigeria economy. For the past 40 years, FDI (foreign direct investments) in African region, especially Nigeria, has been chaotic and erratic in nature. FDI has increased in Nigeria over that duration. However, it is clear that movement of federal direct investments to Nigeria has declined over time as compared to the other developing nations across the globe. For example, in 1980, considering all the flows of FDI to the developing regions across the globe, only 5\% was received in African region, $7 \%$ in Asia, and $86 \%$ in Latin America. The 5\% went to Africa region, and 0.09\% went to Nigeria. By 1990, the proportion of FDI flow that went to Africa was $8 \%$ while Asia and Latin America received 65\% and 26\% respectively. Moreover, in 2015, African region received $10 \%$ of foreign direct investments to developing nations while $62 \%$ and $28 \%$ went to Asia and Latin America respectively (Wilson, 2017) [1]. This portrayed the movements of foreign capital to the African region, particularly to Nigeria, since the rise in flow of capital was not in the equivalent proportion like other developing areas of the globe.

The requirement for FDI comes from the undeveloped nature of Nigeria's economy, which basically, hindered the progress of the country's economic development. Commonly, strategies and policies of the government of Nigeria towards investments from foreign companies are guided by two-principal objects, including the demand to develop the economy and the desire to be economically independent. However, the economy of Nigeria has been expressed as the dual economy whose modern sector relies on the oil earning as well as over established by the traditional trading and agricultural economy (Thomas \& Canagraph, 2018) [2]. Regardless of oil sector's contribution to domestically generated revenues, Nigeria's economic growth since 1970s has been defined as erratic, mainly driven by oil fluctuations in the global market (Dutse, 2015) [3]. Therefore, after realizing the extremely significant role foreign direct investments can contribute in the growth of economy, Nigeria competes with other nations of the globe, especially in African region aggressively, to attract FDI towards its economy.

Foreign direct investment is popularly known as a medium of growth and development of the economy (Bertels \& Combruggshe, 2018) [4]. Additionally, FDI is seen as a primary stimulus to the development of the economy and contributes in an important manner since it is more stable as compared to other capital flow forms (Ajayi, 2018: Mwilima, 2003) [5] [6]. FDI has a recognized ability to handle major obstacles like shortage of skills, technology, and financial resources (Mwilima, 2003) [6]. It is also perceived as an instrument for growth 
since it offers the capital needed for investment, enhances competition in industries of the host nation, and helps local companies to be more productive through investing in physical and human capital or adoption of more advanced and efficient technology. Moreover, it helps to integrate the nation's economy with other parts of the globe and offer management knowledge (Belle \& Adeniyi, 2015) [7].

Foreign direct investments have advanced to be largely seen as the source of a country's economic growth and development, income and employment growth by promoting economies, modernization, emerging market nations, and countries in transition. Therefore, they have liberalized their foreign direct investments frameworks and regimes and vigorously follow policies that will attract foreign investments. For example, the challenge concerning the best way to go after domestic policies that will optimize the gains and benefits of presence of foreigners in the national economy in form of foreign direct investments has gained more consideration. However, regardless of the effect of FDI, the empirical proof on the sources of the host nation economic improvement and FDI inflows has been evasive.

There are numerous studies on FDI's theoretical determinants which, among other factors, have emphasized issues of policy integrity, governance failures, poor liberalization programs, and macro-economic policy failures among others as hindrances to foreign direct investment inflows (Ajayi, 2018) [5]. Therefore, it is against this basis that this research was constrained.

\subsection{Objectives of This Study}

The main objective of the research is to review FDI as factor affecting the economic growth of Nigeria. The study specifically aims to:

1) Analyze the effect of FDI on the manufacturing sectors of Nigeria.

2) Analyze the effect of FDI on the labor force of Nigeria.

3) Analyze the effect of FDI on the inflation of Nigeria.

\subsection{Research Questions}

This study was guided by the following questions:

1) How are the Nigerian manufacturing sectors affected by FDI?

2) How is the labor force of Nigeria affected by FDI?

3) To what level is Nigeria's inflation affected by FDI?

\section{Literature Review}

\subsection{Conceptual Review}

\subsubsection{FDI (Foreign Direct Investments)}

FDI (Foreign direct investments) refer to investments made by an individual or company in one nation for profitability in another nation, either through acquisition of business assets or establishment of business operations in that country, including controlling interests or ownership of a foreign firm (Wilson, 2017) [1]. 
The link between economic development and FDI (foreign direct investments) is one well-researched matter in development of economic literature, both empirically and theoretically. Recently, revived growth in determinants of growth and the significant research on growth lead by external factors, with the anticipation of internal growth theories (Barro, 2018) [8], made it even more possible to include foreign direct investment as one determinant of long-term economic growth. Additionally, the significance on the matter has developed from the considerable increase inflow of FDI that began in the late 1990s, and caused the wave of study based on its determinants.

Regardless of the significant volume of study on the matter, there has been conflicting proof in literature concerning the issue of how FDI affects economic growth. A 2-way synergy has particularly been discussed within the literature of economic growth-FDI relationship. For instance, foreign direct investment is being observed, by most people, as a critical factor that will solve the issue of low productivity in general and scarcity of local capital in most developing nations (De Mello, 2012) [9]. Therefore, the movement of foreign capital is considered to be the potential player that will enhance growth in the host nation. This perspective is opposed by most authors. For instance, Carkovic \& Levine (2017) [10] demonstrate that FDI does not have a robust impact on economic growth, especially if the nation-specific level variations, convergence effects, and endogeneity of foreign direct investment inflows are put into consideration. Additionally, according to Akinlo (2012) [11], both foreign capital and private capital does not have a statistically considerable impact on economic growth. The study established that the outcomes seem to back the debate that extractive foreign direct investment may not be enhancing growth more than manufacturing foreign direct investment.

On the contrary, acknowledging the significance of foreign direct investment to economic growth, the growth itself is frequently identified as a critical determinant, among different determinants, of inflow of FDI into host nations. Rapid economic growth might be more appealing to MNCs (multinational companies), since they detect new profitable opportunity (Hansen \& Rand, 2016) [12].

\subsubsection{Inflation}

Inflation refers to the increases in the prices of services and goods in the economy over time. Once the common price levels increase, every unit of the country's currency purchase fewer services and goods. Therefore, inflation certainly indicates the erosion of the money's purchasing power due to the loss of the actual value in that internal exchange medium and account unit in a country's economy (Nwanya, 2018) [13]. The main appraisal for inflation in price is known as inflation rate, which is the percentage annual change in the general price index (also known as Consumer Price Index (CPI) over time. The effects of inflation on the economy are different and they can be concurrently negative or positive. The negative inflation's effects include increased opportunity cost for holding cash and uncertainty in future inflation, thus discouraging savings and invest- 
ments. Additionally, if the inflation is sufficiently rapid, there will be scarcity of goods since customers will start to hoard goods, thinking that the prices might increase in the future (Orunmoluyi, 2015) [14].

\subsubsection{Labor Force}

The level of underutilized and unutilized labor force in Nigeria is high. This indicates that the country's unemployment rate has become relentless. The asperity on the issue of unemployment in the labor market of Nigeria varies across different areas. According to Akinyosoye (2010) [15], the projected population of Nigeria's working population is about $25 \%$, considering the wage-earners employed in the regular jobs while the remaining $75 \%$ fell under self-employment. A recent Word Bank report claimed that the unemployed population in Nigeria is about 40 million, which is about $29 \%$ of the entire population. The worldwide reality on mass-unemployment can already be seen in Nigeria and it is increasing annually (Babalola, 2017) [16]. According to Norris' perspective, surplus has already surpassed scarcity in a classical equation of supply side (Norris, 2018) [17]. Nonetheless, there is an imbalance between Nigeria's labor market absorptive and supply of the skilled labor. Such an imbalance has resulted in increased dependency ratio, brain drain, productivity decrease, a decrease in the national output as well as increases cases of crimes, and social vices (especially kidnapping). This is mainly the case when Okun law is considered, such that there is a $1 \%$ decrease in employment rate, thus implying a decline of $3 \%$ in total output.

\subsubsection{Manufacturing}

The sector of manufacturing is largely relevant in growth of every country, particularly the undeveloped or underdeveloped nations. Moreover, over the past years, most economists have debated the major causes as well as the mechanism behind economic development. Industrialization is considered to be the main driving force of modern economy. The industrial sector of numerous modern economies acts as the driving force for production of services and goods, income enhancement, and employment creation. Therefore, Kayode (2011) [18] explained the industry, especially the sub-sector of manufacturing, as the economy's heart. Nigeria has deployed numerous strategies with the aim of enhancing the sector's economy so as to promote economic development and growth. For example, the nation adopted the strategy of imports substitution industrialization during the $1^{\text {st }}$ plan of national development (1962-1968), that aimed at minimizing the imports' volume of the finished goods, thus encouraging savings of foreign exchange through local production of some consumer goods that were being imported. The nation consolidated its strategy of substituting import industrialization during the $2^{\text {nd }}$ period of the national development plans (1970-1974) that took place amid the boom era of oil. During this period, activities of the manufacturing sectors were very organized to rely on the imported inputs due to the weak economic technological base. Nonetheless, because of the downfall of world oil-market in 1980s, there was severe decline in oil export 
earnings. Therefore, the import-reliant industrial structure which had developed became unsustainable because of the insufficiency in oil export earnings which could not sufficiently manage large bills from imports.

\subsection{Theoretical Framework}

\section{H-O (Heckscher-Ohlin) Theory}

This theory that determines the trade pattern of a country was developed from Ohlin (1933) and Heckscher (1919) [19] in Sweden. The theory claims that the commodities needed for production (a bit of the scarce resources and a lot of abundant production factors) are mostly exported so that they can be exchanged with goods that need factors in opposite proportions. Therefore, factors that are in abundant supplies are exported indirectly and the factors in scarce supply imported. H-O theory anticipates that nations export those products that intensively use the abundant factors and import those products that utilize their scarce factors or resources intensively. A nation is relatively labor-abundant, if the percentage of labor to other production factors is high as compared to other parts of the globe. Additionally, a product is considered to be labor-intensive, if the cost of labor has a larger value of share as compared to other product's value.

The theory of factor endowment states that high-skilled labor (human capital/technical workers) and physical (non-human) capital are in abundance in the industrialized nations. However, unskilled labor in developed nations is scarce. This indicates that opposite pattern in the scarcity and abundance of high skilled labor, unskilled labor, and physical capital is common in the underdeveloped nations. Thus, developing nations have an inadequate provision of technology, skilled human labor, and physical capital.

\subsection{Empirical Review}

A research on the relationship between textile manufacturing companies in $\mathrm{Ni}$ geria and FDI was conducted by Anyanwu (2016) [20]. The research was undertaken using two Nigerian textile companies. It was streamlined using two research questions while the survey questions were adopted. The study used secondary data as well as gathered data that was subsequently analyzed with Pearson moments correlation. Findings of this research revealed that foreign direct investments have a considerable effect on the textile manufacturing companies.

Gorge \& Stroble (2013) [21] analyzed the impact of foreign direct investments on labor forces utilizing 12 manufacturing firms in Thailand. This research had 3 research questions while the expo facto approach was utilized. The secondary data used was gathered from the stock exchange of Thailand and then analyzed with E-view using the simple linear regression. Findings of this research indicated that foreign direct investments affect the labor force considerably.

A research on the effect of FDI on the inflation of Nigeria was conducted by Ninsin (2009) [22]. This research was established using 3 research questions while the descriptive approach was utilized. The secondary data used was gathered from the statistical bulletin of Nigeria and it was then analyzed using the 
simple linear progression method with the use of SPSS (Statistical package of social sciences). Findings of this research indicated that foreign direct investments affect inflation.

A research on the effect of Fiscal Incentive in Attracting FDI to Sub-saharan African was conducted by Wilson (2017) [1]. This research was established using 3 research questions while the descriptive approach was utilized. The secondary data used was gathered from the statistical bulletin of Nigeria and it was then analyzed using the simple linear progression method with the use of SPSS (Statistical package of social sciences). Findings of this research indicated that fiscal incentives attract foreign direct investments.

\subsection{Summarizing the Literature Review/Gap in the Literature}

The research paid close attention to FDI as a determinant of the economic growth of Nigeria. The research discussed the implication of FDI, labor force, inflation, and the manufacturing sector. The research was based on the $\mathrm{H}-\mathrm{O}$ (Heckscher-Ohlin) theory. Regarding the literature review, it was seen that several studies on FDI have been undertaken, but there is no study that reviewed foreign direct investments in regard to labor forces, inflation, and manufacturing sectors of Nigeria, a gap that this study intends to cover.

\subsection{Research Hypotheses}

The null hypotheses that guided this research include:

$\mathrm{H}_{\mathrm{ol}}$ : FDI does not have a significant effect on the manufacturing sectors of Nigeria.

$\mathrm{H}_{\mathrm{o} 2}$ : FDI does not have a significant effect on the labor force of Nigeria.

$\mathrm{H}_{\mathrm{o} 3}$ : FDI does not have a significant effect on the inflation of Nigeria.

\section{Methodology}

\subsection{Estimation Procedure}

In order to activate the objective of the study, the major forces are to determine the implication of FDI on economic growth in Nigeria. The ordinary least square (OLS) techniques are adopted to determine the equation with the use of E-view. OLS is adopted to guard against bias and obtain the appropriate association of values measure. The study captured equations specified so as to test the relationship between the dependent and independent variables. The study also examines the relationship between FDI and manufacturing sectors, FDI and labor force, FDI and inflation of Nigeria.

\subsection{Source of Data}

The study will use only secondary data. These data would be sourced from Central Bank of Nigeria Statistical Bulletin Publications from National Bureau of Statistics, Internet, Newspaper, Articles, Journals and World Bank Publications [23]. 


\section{Data Required}

The following data were required for analyzing data. The data include:

Data on manufacturing sector for 10 years

Data on Foreign direct investment for 10 years

Data on labour forces for 10 years

Data on inflation for 10 years and

\subsection{Sample Frame}

The data was collected on the variables of interest on foreign direct investment in Nigeria. The sample point for the variable is 2009 to 2018 . These variables include: foreign direct investment manufacturing, labour force and inflation.

\subsection{Model Estimation and Validation of Instrument}

The validity and reliability of the instrument was determined using ordinary least square (OLS) technique. The technique is the best linear unbiased estimator. To test the validity of the method, the following statistical econometric tests were carried out:

1) T-test refers to the estimated regression coefficient test. This will enable us ascertain the statistical reliability of the regression coefficient in the model specified and used in the study.

2) ( $R^{2}$ coefficient): This represents the adjusted coefficient of determined and is adopted to determine fitness of the model.

3) F-test or F-ratio: This tests the overall significance of the regression.

4) Standard error test: This is used to test for statistical reliability of the co-efficient estimates.

5) Durbin Watson: This aids in examining the extent of serial co-relation in the study.

\section{Model Specification and Validation}

\section{Equation}

To examine the impact of FDI with respect to economic growth, the following estimations are carried out:

$$
\mathrm{FDI}=f(\mathrm{LABF}, \mathrm{MAN}, \mathrm{INF}) e_{t}
$$

This model is restated in econometric form as follows:

$$
\mathrm{FDI}=a_{0}+a_{1} \mathrm{LLABF}+a_{2} \mathrm{LMAN}+a_{3} \mathrm{LINF}+e_{t}
$$

where:

$$
\begin{aligned}
& e_{t}=\text { Stochastic or error term } \\
& \text { LLABF }=\text { Log of Labour Force } \\
& \text { LMAN = Log of Manufacturing } \\
& \text { LINF = Log of Inflation }
\end{aligned}
$$

\section{Data Presentation and Analysis}

This chapter covered the presentation and analysis of data collected. This data outlined in Table 1, is meant for the empirical investigation. Here, regression 
Table 1. Data presentation on manufacturing, inflation, FDI and labour force.

\begin{tabular}{ccccc}
\hline Year & $\begin{array}{c}\text { Manufacturing } \\
\text { MANU }\end{array}$ & Inflation & $\begin{array}{c}\text { Foreign Direct Investment } \\
\text { (FDI) (Billions) }\end{array}$ & $\begin{array}{c}\text { Labour } \\
\text { force }\end{array}$ \\
\hline 2009 & 56.6 & 12.169 & 61.911 & $433,203.5$ \\
2010 & 41 & 23.811 & 60.677 & $356,994.3$ \\
2011 & 73.25 & 10.008 & 62.207 & $433,203.5$ \\
2012 & 48.0 & 11.565 & 63.434 & $329,178.7$ \\
2013 & 59.3 & 8.500 & 61.14 & $312,183.5$ \\
2014 & 49.0 & 6.566 & 64.415 & $329,178.7$ \\
2015 & 64 & 15.148 & 64.107 & 541,652 \\
2016 & 67.0 & 13.936 & 74.279 & $213,451.5$ \\
2017 & 61.0 & 11.742 & 63.107 & 477,533 \\
2018 & 70.2 & 15.03 & 43.428 & $205,222.1$ \\
\hline
\end{tabular}

Sources: Central Bank of Nigeria (CBN), NSE Statistical Bulletin (Various issues), 2019 [23].

was run so as to be equipped for the interpretation and also to provide solution to the research questions in respect to FDI and economic development

\section{FDI equation}

$$
\mathrm{FDI}=f(\mathrm{LABF}, \mathrm{MAN}, \mathrm{INF}) e_{t}
$$

\section{Analysis of Hypotheses Using E-View 9}

\section{Level of significance $=0.05$}

\section{Hypothesis I}

$\mathrm{H}_{\mathrm{o}}$ : foreign direct investment has no significant impact on manufacturing sectors in Nigerian

$\mathrm{H}_{1}$ : foreign direct investment has a significant impact on manufacturing sectors in Nigerian

\begin{tabular}{|c|c|c|c|c|}
\hline \multicolumn{5}{|c|}{ Dependent Variable: FDI } \\
\hline \multicolumn{5}{|c|}{ Method: Least Squares } \\
\hline \multicolumn{5}{|c|}{ Date: $22 / 01 / 20$ Time: 00:10 } \\
\hline \multicolumn{5}{|c|}{ Sample: 2009-2018 } \\
\hline \multicolumn{5}{|c|}{ Included observations: 10} \\
\hline Variable & Coefficient & Std. Error & t-Statistic & Prob. \\
\hline $\mathrm{C}$ & 75.54380 & 19.89115 & 3.797859 & 0.0067 \\
\hline MANU & 0.155879 & 0.274514 & 0.567836 & 0.5879 \\
\hline INF & -0.349219 & 0.603485 & -0.578670 & 0.5809 \\
\hline R-squared & 0.768999 & \multicolumn{2}{|c|}{ Mean dependent var } & 61.87050 \\
\hline Adjusted R-squared & 0.897001 & \multicolumn{2}{|c|}{ S.D. dependent var } & 7.539669 \\
\hline S.E. of regression & 8.248966 & \multicolumn{2}{|c|}{ Akaike info criterion } & 7.301378 \\
\hline Sum squared resid & 476.3181 & \multicolumn{2}{|c|}{ Schwarz criterion } & 7.392153 \\
\hline Log likelihood & -33.50689 & \multicolumn{2}{|c|}{ Hannan-Quinn criter. } & 7.201797 \\
\hline F-statistic & 0.259396 & \multicolumn{2}{|c|}{ Durbin-Watson stat } & 1.257755 \\
\hline Prob (F-statistic) & 0.008619 & & & \\
\hline
\end{tabular}


From the analysis, the regression equation is given as follows

$$
\text { FDI }=75.54380+0.1558 \mathrm{MANU}-0.3492 \mathrm{INF}
$$

From the analysis, it shows that for every unit increase in FDI, manufacturing increases by 0.1558 , inflation decreases by 0.3492 . The analysis also shows that FDI was explained by MANU and INFL up to 89 percent (R-square). From the analysis, it was also observed that the probability value $(0.008)$ is less than the alpha value (0.05), the researcher therefore accept the alternative hypothesis and concludes that foreign direct investment has a significant impact on manufacturing sectors in Nigerian.

\section{Hypothesis II}

$\mathrm{H}_{\mathrm{o}}$ : foreign direct investment has no significant impact on labour force in $\mathrm{Ni}$ gerian

$\mathrm{H}_{1}$ : foreign direct investment has a significant impact on labour force in Nigerian

\begin{tabular}{|c|c|c|c|c|}
\hline \multicolumn{5}{|c|}{ Dependent Variable: FDI } \\
\hline \multicolumn{5}{|c|}{ Method: Least Squares } \\
\hline \multicolumn{5}{|c|}{ Date: $22 / 01 / 20$ Time: 00:09 } \\
\hline \multicolumn{5}{|c|}{ Sample: $2009-2018$} \\
\hline \multicolumn{5}{|c|}{ Included observations: 10} \\
\hline Variable & Coefficient & Std. Error & $\mathrm{t}$-Statistic & Prob. \\
\hline $\mathrm{C}$ & 59.99816 & 12.18218 & 4.925075 & 0.0017 \\
\hline LBF & $1.41 \mathrm{E}-05$ & $2.52 \mathrm{E}-05$ & 0.559900 & 0.5930 \\
\hline INF & -0.253573 & 0.581969 & -0.435715 & 0.6762 \\
\hline R-squared & 0.867860 & \multicolumn{2}{|c|}{ Mean dependent var } & 61.87050 \\
\hline Adjusted R-squared & 0.798466 & \multicolumn{2}{|c|}{ S.D. dependent var } & 7.539669 \\
\hline S.E. of regression & 8.254012 & \multicolumn{2}{|c|}{ Akaike info criterion } & 7.302601 \\
\hline Sum squared resid & 476.9010 & \multicolumn{2}{|c|}{ Schwarz criterion } & 7.393376 \\
\hline Log likelihood & -33.51300 & \multicolumn{2}{|c|}{ Hannan-Quinn criter. } & 7.203020 \\
\hline F-statistic & 0.254801 & \multicolumn{2}{|c|}{ Durbin-Watson stat } & 1.502663 \\
\hline Prob (F-statistic) & 0.001959 & & & \\
\hline
\end{tabular}

From the analysis, the regression equation is given as follows

$$
\mathrm{FDI}=59.99816+1.41 \mathrm{E}-05 \mathrm{LBF}-0.2535 \mathrm{INF}
$$

From the analysis, it shows that for every unit increase in FDI, labour force increases by 1.41 , inflation decreases by 0.253 . The analysis also shows that FDI was explained by labour force and inflation up to 86 percent (R-square). From the analysis, it was also observed that the probability value $(0.001)$ is less than the alpha value (0.05), the researcher therefore accept the alternative hypothesis and concludes that foreign direct investment has a significant impact on labour force in Nigerian. 


\section{Hypothesis III}

$\mathrm{H}_{\mathrm{o}}$ : foreign direct investment has no significant impact on inflation in Nigerian

$\mathrm{H}_{1}$ : foreign direct investment has a significant impact on inflation in Nigerian

\begin{tabular}{|c|c|c|c|c|}
\hline \multicolumn{5}{|c|}{ Dependent Variable: FDI } \\
\hline \multicolumn{5}{|c|}{ Method: Least Squares } \\
\hline \multicolumn{5}{|c|}{ Date: $22 / 01 / 20$ Time: $00: 11$} \\
\hline \multicolumn{5}{|c|}{ Sample: 2009-2018 } \\
\hline \multicolumn{5}{|c|}{ Included observations: 10} \\
\hline Variable & Coefficient & Std. Error & $\mathrm{t}$-Statistic & Prob. \\
\hline $\mathrm{C}$ & 70.24202 & 23.38843 & 3.003280 & 0.0239 \\
\hline INF & -0.343032 & 0.637893 & -0.537758 & 0.6101 \\
\hline LBF & $1.38 \mathrm{E}-05$ & $2.67 \mathrm{E}-05$ & 0.517123 & 0.6236 \\
\hline MANU & 0.152206 & 0.290201 & 0.524486 & 0.6187 \\
\hline R-squared & 0.808723 & \multicolumn{2}{|c|}{ Mean dependent var } & 61.87050 \\
\hline Adjusted R-squared & 0.836916 & \multicolumn{2}{|c|}{ S.D. dependent var } & 7.539669 \\
\hline S.E. of regression & 8.717747 & \multicolumn{2}{|c|}{ Akaike info criterion } & 7.457773 \\
\hline Sum squared resid & 455.9947 & \multicolumn{2}{|c|}{ Schwarz criterion } & 7.578807 \\
\hline Log likelihood & -33.28887 & \multicolumn{2}{|c|}{ Hannan-Quinn criter. } & 7.324999 \\
\hline F-statistic & 0.243971 & \multicolumn{2}{|c|}{ Durbin-Watson stat } & 1.486063 \\
\hline Prob (F-statistic) & 0.002827 & & & \\
\hline
\end{tabular}

From the analysis, the regression equation is given as follows

$$
\mathrm{FDI}=59.99816+1.41 \mathrm{E}-05 \mathrm{LBF}-0.2535 \mathrm{INF}
$$

From the analysis, it shows that for every unit increase in FDI, inflation increases by 0.343032 , labour force increase by 1.38 , manufacturing increases by 0.152 . The analysis also shows that FDI was explained by labour force, manufacturing and inflation up to 80 percent (R-square). From the analysis, it was also observed that the probability value $(0.002)$ is less than the alpha value $(0.05)$, the researcher therefore accept the alternative hypothesis and concludes that foreign direct investment has a significant impact on inflation in Nigerian.

\section{Conclusion and Recommendation}

Having done the analysis, the researcher concludes that foreign direct investment has a significant impact on manufacturing sectors, labour force and inflation in Nigerian. Given the above situation and the fact that Nigeria's economic recovery efforts and growth require major private sector investment in modern equipment that can industrialize the economy as a whole, then Nigeria's foreign investment policy should move towards attracting and encouraging more in- 
flows of foreign capital by moving ahead with economic programmes that include measures easier set up and expansion of businesses. With the up and down movement of foreign direct investment, Nigeria needs to juxtapose foreign investment with domestic investment in order to maintain high levels of income and employment. Also the Nigerian government should encourage the inflows of foreign direct investment and contact policy institutions that can ensure the transparency of the operations of foreign companies within the economy. Finally, in evaluating foreign direct investment, the screening process should be simplified and improved upon. For example, export investment projects that consistently generate positive contribution to national income can be screened separately and swiftly, while projects in import competing industries should be screened separately.

\section{Conflicts of Interest}

The authors declare no conflicts of interest regarding the publication of this paper.

\section{References}

[1] Wilson, E. (2017) Effect of Fiscal Incentive in Attracting FDI to Sub-Saharan African. IAABD 5 th International Conference, Atlanta, 18 August 2017, 22-25.

[2] Thomas, F. and Canagraph, Y. (2018) FDI-LED Growth Hypothesis in ASEAN 5 Countries: Evidence from Co Integrated Panel Analysis. International Journal of Business and Management, 14, 12-14.

[3] Dutse, J.H. (2015) Re-Evaluating the Benefits of Foreign Direct Investment. Transnational Corporations, 3, 23-51.

[4] Bertels, R.E. and Combruggshe, E.Y. (2018) Exchange Rate Movement and Foreign Direct Investment in the United State. New York University Press, New York.

[5] Ajayi, C. (2018) Foreign Direct Investment, Non-Oil Export and Economic Growth in Nigeria: A Causality Analysis. Annual Conference on Africa.

[6] Mwilima, J.C. (2003) Exchange Rates and Foreign Direct Investment: An Imperfect Capital Market Approach. Quarterly Journal of Economics, 4, 1191-1217.

[7] Belle, N. and Adeniyi, S. (2015) Dynamics Linkages among Foreign Direct Investment, Public Investment and Private Investment: Evidence from Turkey. Applied Econometrics and International Development, 5, 71-82.

[8] Barro, M. (2018) Determinant of Foreign Direct Investment Flows to Developing Countries: A Cross Sectional Analysis. Prague Economic Paper, 4, 380-369.

[9] De Mello, S. (2012) Factor Attracting FDI to Nigeria: An Empirical Investigation. Madras School of Economics, Gandi Mandapam Road Kottur, Chennia.

[10] Carkovic, V. and Levine, K. (2017) Trend and Determinant of New Inward Foreign Direct Investment to South Africa.

[11] Akinlo, J.A. (2012) Foreign Private Investment: Issues, Determinants and Performance. Workshop on Foreign Investment Policy and Practice, Ibadan, 22 April 2012, 12-13.

[12] Hansen and Rand, M.I. (2016) Exchange Rate Determination, Foreign Investment Burden and External Debt Crisisless Developed Countries: Nigeria Experience. In- 
ternational Journal of Business and Economics Perspective, 2, 91.

[13] Nwanya, S. (2018) Foreign Direct Investment and the Environment in Developing Economies. Environmental Research Journal, 4, 291-297. https://doi.org/10.3923/erj.2010.291.297

[14] Orunmoluyi, G.O. (2015) Foreign Private Capital Flows to Nigeria 2002-2013. Journal of Economic and financial Review, 4, 45-47.

[15] Akinyosoye, L. (2010) FDI Inflow to Low Income Countries: Global Drivers and Growth Implication. IMF Working Paper, 29, 255-271.

[16] Babalola, A.Y. (2017) Nigerian Economic Growth: Emphasizing the Role of Foreign Direct Investment in Transfer of Technology. Communication of IBIMA, 3, 76-83.

[17] Norris, M.I. (2018) The Determinants of Foreign Investment in African Countries. Journal of Management Sciences, 2, 44-45.

[18] Kayode, J.K. (2011) Foreign Direct Investment, Industrialisation and Social Change. Contemporary Studies in Economic and Financial Analysis, Vol. 9, Nabu Press, Charleston, 56-60.

[19] Heckscher, H. (1919) Theory of Trade Endowment Production.

[20] Anyanwu, N. (2016) Conducted a Study on Relationship between Foreign Direct Investment and Textile Manufacturing Firms in Nigeria. Journal of Management Science, 2, 33-34.

[21] Gorge, S. and Stroble, Z. (2013) Influence of FDI on Labour Forces in Thailand. Journal of Management Science, 2, 33-34.

[22] Ninsin, S. (2009) Impact of FDI on Nigerian Inflation. Journal of Management Science, 2, 33-34.

[23] Central Bank of Nigeria (CBN) (2019) NSE Statistical Bulletin (Various Issues). 